\title{
RETARDATION OF THE REACTION OF LITHIUM HYDRIDE WITH WATER VAPOR
}

\author{
C. E. Holcombe
}

\section{Oak Ridge Y-12 Plant}

P.O. Box Y, Oak Ridge, Tennessee 37830

operated for the U.S. ATOMIC ENERGY COMMISSION bY UNION CARBIDE CORPORATION-NUCLEAR DIVISION under Contract W-7405-eng-26

Date Issued - July 28, 1972

This report was prepared as an account of work sponsored by the United States Government. Neither the United States nor the United States Atomic Energy Commission, nor any of their employees, nor any of their contractors, subcontractors, or their employees, makes any warranty, express or implied, or assumes any legal liability or responsibility for the accuracy, completeness or usefulness of any information, apparatus, product or process disclosed, or represents that its use would not infringe privately owned rights.

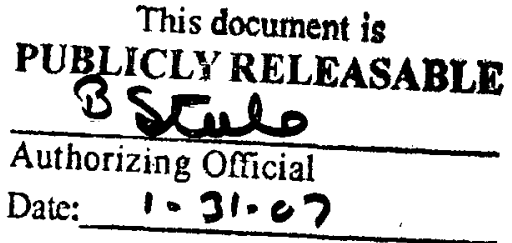




\section{DISCLAIMER}

This report was prepared as an account of work sponsored by an agency of the United States Government. Neither the United States Government nor any agency Thereof, nor any of their employees, makes any warranty, express or implied, or assumes any legal liability or responsibility for the accuracy, completeness, or usefulness of any information, apparatus, product, or process disclosed, or represents that its use would not infringe privately owned rights. Reference herein to any specific commercial product, process, or service by trade name, trademark, manufacturer, or otherwise does not necessarily constitute or imply its endorsement, recommendation, or favoring by the United States Government or any agency thereof. The views and opinions of authors expressed herein do not necessarily state or reflect those of the United States Government or any agency thereof. 


\section{DISCLAIMER}

Portions of this document may be illegible in electronic image products. Images are produced from the best available original document. 


\begin{abstract}
An investigation was made into the possibility of retarding the reaction of lithium hydride with water vapor by forming lithium carbonate or lithium fluoride layers. It was found that the reaction rate in a ten percent relative humidity atmosphere was linear with time at room temperature for treated or untreated samples. A 19 percent decrease in the rate of water pickup occurred for carbon dioxide-treated samples, whereas a 31 percent decrease resulted for fluorine-treated samples.
\end{abstract}


CONTENTS

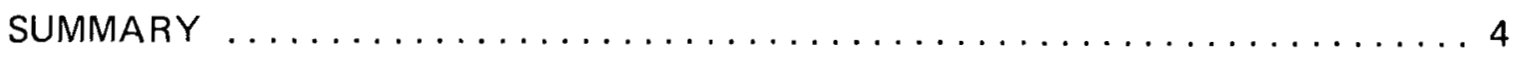

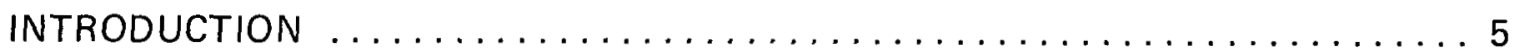

RETARDING THE ACTION OF WATER VAPOR WITH LITHIUM HYDRIDE $\ldots . . .6$

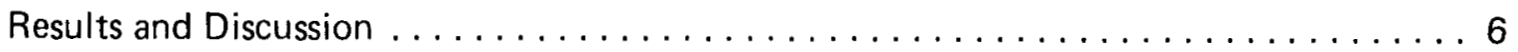

Lithium Carbonate Layer . . . . . . . . . . . . . . . . . . . . . 6

Lithium Fluoride Layer . . . . . . . . . . . . . . . . . . . . . . 9

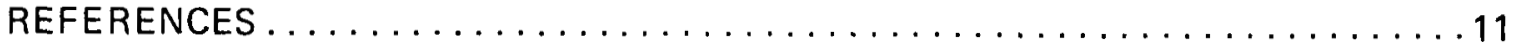

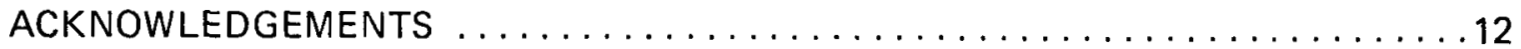




\section{SUMMARY}

An examination was made of the effect of carbon dioxide and fluorine treatments on the reaction of hot-pressed $(\sim 99.5 \%$ dense) lithium hydride with water vapor. The weight gain-versus-time relationship (taken in a $10 \% \mathrm{RH}$ room) was found to have a linear relation for both the untreated and treated specimens. The linear relation implies a complex diffusion-controlled process.

Carbon dioxide exposures to lithium hydride caused a 19 percent decrease in the rate of water pickup over the 700-hour exposure period in a ten percent relative humidity atmosphere. However, for the first 24 hours after the initial carbon dioxide treatment, an effective 50 percent reduction of the reaction of lithium hydride with water vapor occurred.

Fluorine treatments caused a 31 percent decrease in the rate of water pickup over a 385-hour exposure to a ten percent relative humidity atmosphere. 


\section{INTRODUCTION}

Studies of the kinetics of the reaction of lithium metal ${ }^{(1)}$ and lithium hydride ${ }^{(2)}$ with water vapor have been reported in the literature. Formation of chemically unreactive (with respect to water vapor) species on the surface of lithium hydride would be expected to alter its reaction rate. Thus, reactions of lithium hydride with water might be significantly reduced if such layers were impervious.

It has been established (2) that lithium hydride reacts readily with water to form lithium hydroxide or lithium hydroxide monohydrate, both of which form lithium carbonate when exposed to carbon dioxide. Since lithium carbonate has a low solubility in water (15 $\mathrm{mgs} / \mathrm{cc}$ ), a lithium carbonate layer was thought to be a good choice for retarding the lithium hydride-water reaction. The sequence necessary to form the layer would involve: (1) controlled exposure to moisture to form a lithium hydroxide outer layer, and then (2) reaction with carbon dioxide to form the lithium carbonate layer.

Another possible passivating layer might be lithium fluoride. Since lithium fluoride (face-centered cubic with an $a_{O}=4.017 \mathrm{~A}$ ) is structurally identical $(3)$ with lithium hydride (face-centered cubic with an $a_{0}=4.083 \mathrm{~A}$ ), a replacement of the negative hydrogen ions on a lithium hydride surface with fluoride ions might lead to a coherent lithium fluoride layer on lithium hydride. The presence of a completely impervious layer of lithium fluoride, which does not react with water vapor and has a low solubility in water $(3 \mathrm{mgs} / \mathrm{cc}$ ), could prevent the reaction of lithium hydride with water vapor. The lithium fluoride layer could be prepared by ion sputtering, vapor deposition, or a replacement reaction ( $F^{-}$for $\left.\mathrm{H}^{-}\right)$. The latter method was chosen because of its simplicity. 


\section{RETARDING THE ACTION OF WATER VAPOR WITH LITHIUM HYDRIDE}

\section{RESULTS AND DISCUSSION}

Sample discs (2" D $\left.\times 0.125^{\prime \prime} \mathrm{T}\right)$ of polycrystalline, hot-pressed lithium hydride were machined in dry nitrogen. The density of the material was approximately 99.5 percent of the theoretical density for lithium hydride. A 60-mil hole was drilled in the center of the discs in order to suspend them (for weight gain determinations) by means of a 30-mil stainless steel wire from a ring stand. The discs were not exposed to dry-room air $(10 \% \mathrm{RH})$ before the onset of the experiments.

\section{Lithium Carbonate Layer}

A calculation of the surface areas $\left(45.6 \mathrm{~cm}^{2}\right)$ of the discs led to a predicted value of approximately 60 layers of lithium hydroxide for a $0.1-\mathrm{mg}$ weight gain. Since this weight is equal to the maximum sensitivity of the balance used, a $1.0-\mathrm{mg}$ weight gain (corresponding to approximately 600 molecular layers of $\mathrm{LiOH}$ ) was selected as the amount of lithium hydroxide desired on the lithium hydride surface before its reaction with carbon dioxide. Preliminary results showed that the weight gained after a 16-hour exposure of a disc to the dry room air $(10 \% \mathrm{RH})$ was essentially one milligram. Five samples of lithium hydride were randomly picked for control and five for carbon dioxide treatment. These discs were suspended (spaced equidistant from each other) from two ring stands in the dry room for the tests. The sample history is reviewed in Table 1. The argon and carbon dioxide exposures were facilitated by the use of plastic, inflatable glove boxes. Thus, all samples (control and $\mathrm{CO}_{2}$ exposed) were given a 700-hour air treatment (in steps), and all five of the carbon dioxide-exposed samples were given a total of 66 hours of exposure to carbon dioxide (in steps).

Table 1

LITHIUM HYDRIDE SAMPLE HISTORY

\begin{tabular}{ccccc}
\hline \multicolumn{2}{c}{ Five Control Samples } & \multicolumn{2}{c}{ Five Carbon Dioxide-Exposed Samples } \\
\cline { 2 - 5 } $\begin{array}{c}\text { Total Time of Air Exposure } \\
\begin{array}{c}\text { Prior to Argon Exposure } \\
\text { (hrs) }\end{array}\end{array}$ & $\begin{array}{c}\text { Argon Exposure } \\
\text { Time } \\
\text { (hrs) }\end{array}$ & $\begin{array}{c}\text { Total Time of Air Exposure } \\
\text { Prior to Carbon Dioxide } \\
\text { (hrs) }\end{array}$ & $\begin{array}{c}\text { Carbon Dioxide Exposure } \\
\text { Time } \\
\text { (hrs) }\end{array}$ \\
\hline 16 & 30 & 16 & 30 \\
58 & 6 & 58 & 6 \\
148 & 6 & 148 & 6 \\
316 & 24 & 316 & 24 \\
\hline
\end{tabular}

Results of the exposures are reported in Figure 1 for the control samples and in Figure 2 for the carbon dioxide-exposed samples. Thus, the weight gain $\left(\mathrm{mgs} / \mathrm{cm}^{2}\right)$ with time (reaction of $\mathrm{LiH}$ with $\mathrm{H}_{2} \mathrm{O}$ ) is represented by a linear fit. The parameters of the equation $(Y=A+B X)$ are listed in Table 2 along with the statistical measurements. The carbon dioxide exposures caused a 19 percent decrease in the slope of the weight gain-versus-time relation (or a $19 \%$ decrease in the rate of water pickup) over the 700 -hour dry exposure. However, for the first 24 hours after the inital carbon dioxide treatment, a 50 percent reduction in weight gain resulted, due to the reaction of lithium hydride with water. Thus, 


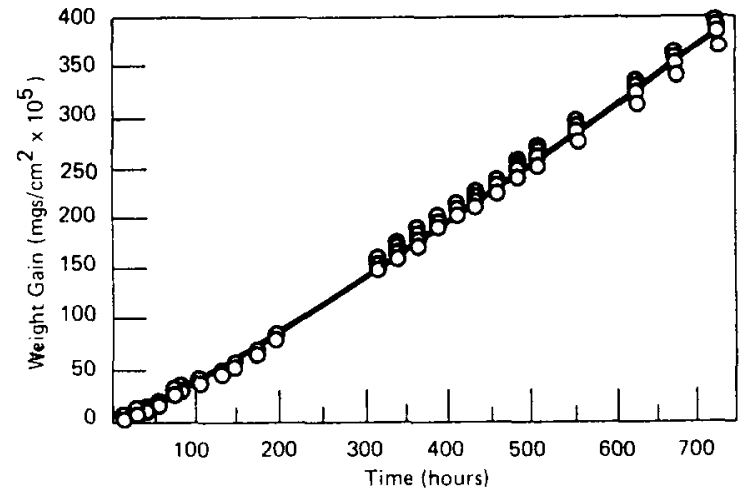

Figure 1. WEIGHT GAIN AS A FUNCTION OF TIME FOR THE FIVE LITHIUM HYDRIDE CONTROL SAMPLES $(Y=A+B X$ FIT $)$ USED WITH THE CARBON DIOXIDE-EXPOSED SAMPLES.

the carbon dioxide exposure was very effective in reducing the reaction of lithium hydride with water vapor for 24 hours.

The linear relation of weight gain versus time indicates that the reaction of lithium hydride with water vapor may not be diffusion controlled. Irvine and Lund(1) found that a linear reaction form applied to the reaction of lithium metal with water vapor, and attributed the linear rate to surface microcracking and lattice diffusion.Machin and Tompkins ${ }^{(2)}$ studied the reaction of water with lithium hydride and concluded that the pickup of water is unchanged (a linear reaction rate) when the hydride is covered with varying thicknesses of either lithium hydroxide or lithium oxide. They also stated that it was extremely unlikely that diffusion of water through the product layer is, at any stage, rate controlling.

All discs were examined by scanning electron microscopy (SEM) after 1,000 to 1,100 hours of total exposure to dry-room air. Figure 3(a) provides a view of an area taken after fracturing a disc. The fractured polycrystals of lithium hydride, the lithium hydroxide broken surface, and the top surface of the lithium hydroxide layer can be seen. View(b) shows the lithium hydroxide layers as they appear on the top surface of the disc and on the side. Machining marks (parallel lines) can be seen on the lithium hydroxide layer on the side of the disc. Splitting of the lithium hydroxide layers at the corners is also apparent. View (c) shows the flared appearance of the lithium hydroxide layer at the corners. There was no difference in the microstructural appearance of the control or carbon dioxide-treated samples.

Since microcracking of the lithium hydroxide layer was not apparent, another mechanism which would continually allow unreacted lithium hydride to come in contact with water 

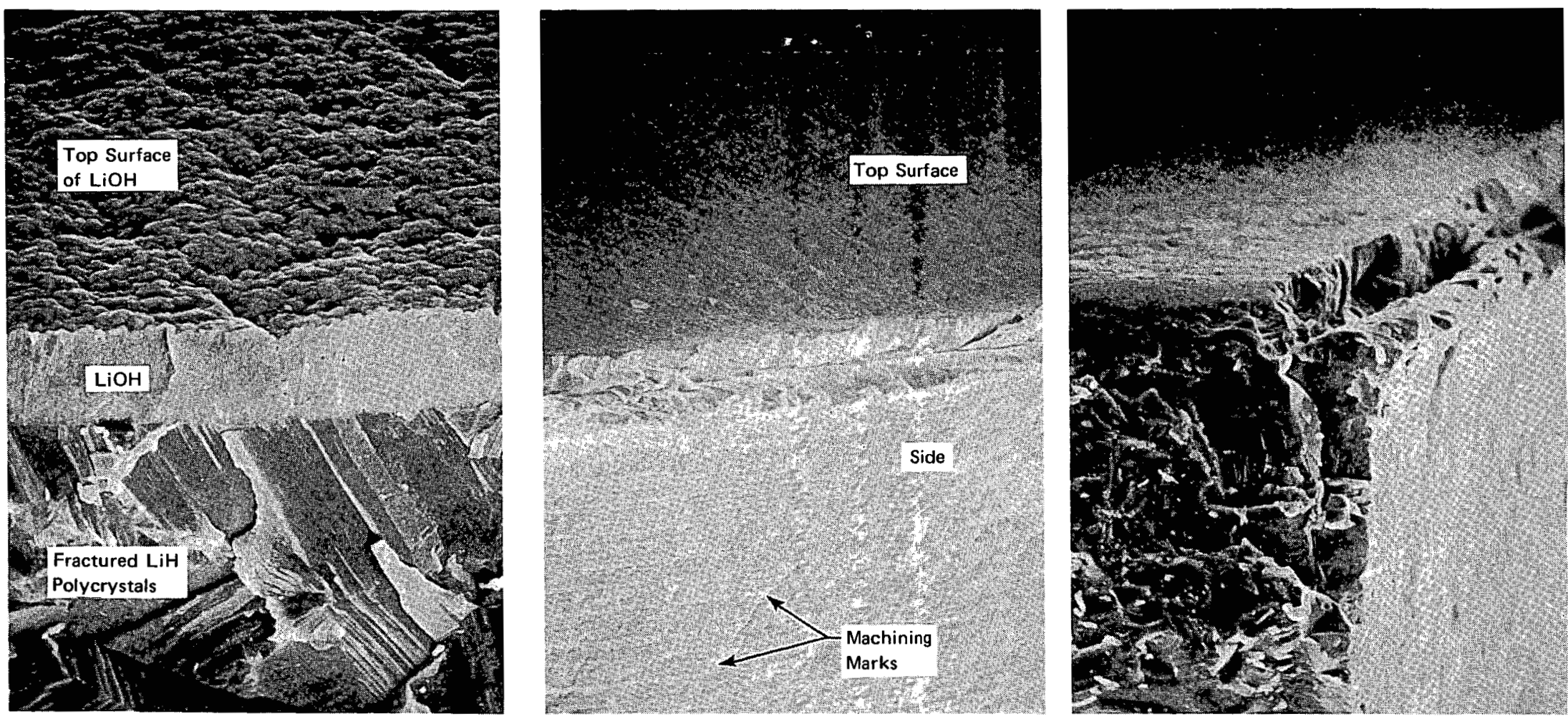

Figure 3. REPRESENTATIVE AREAS OF DISCS USED IN WEIGHT GAIN-VERSUS-TIME EXPERIMENT AFTER 1,000 TO 1,100 HOURS OF TOTAL EXPOSURE TO DRY-ROOM AIR.

o. 
must be occurring. Simple diffusion is unlikely because of the linear relationship of weight gain versus time. The lithium hydroxide layer occurring on single crystals was observed to be oriented. If, for each grain of polycrystalline lithium hydride, an oriented film of lithium hydroxide grew, the result might explain this linear rate. The oriented polycrystalline lithium hydroxide grew on the (100) faces of the lithium hydride single crystal such that the (110) and (220) planes were alternately stacked. The (110) planes contain only lithium ions, and the (220) planes contain only hydroxide ions. Also, the structure of this coherent lithium hydroxide is quite open, which would allow rapid transport of water to be unreacted lithium hydride substrate. This action could keep the reaction rate constant, and preserve a linear reaction rate.

\section{Lithium Fluoride Layer}

Two samples each of the controlled and fluorine-treated lithium hydride were tested. The fluorine treatment was for 15 minutes at $1 / 2$ atmosphere pressure of a $1 / 2$ percent fluorine-in-nitrogen mixture. Care was taken to minimize any air exposure because of handling during the fluorine treatment. A wire basket was used to hold the lithium hydride samples with minimum contact with stainless steel wire through the center of the samples. This arrangement also gave maximum exposure of the surface area of the samples to

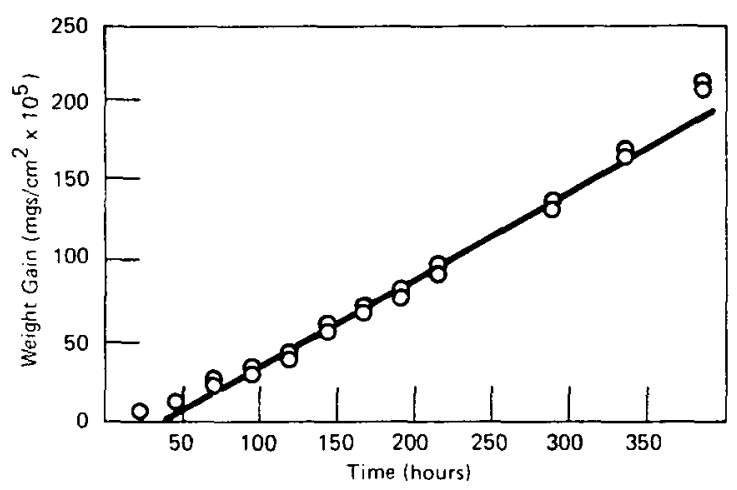

Figure 4. WEIGHT GAIN AS A FUNCTION OF TIME FOR THE CONTROL SAMPLES $(Y=A+B X$ FIT $)$ USED WITH THE FLUORINE-EXPOSED SAMPLES.

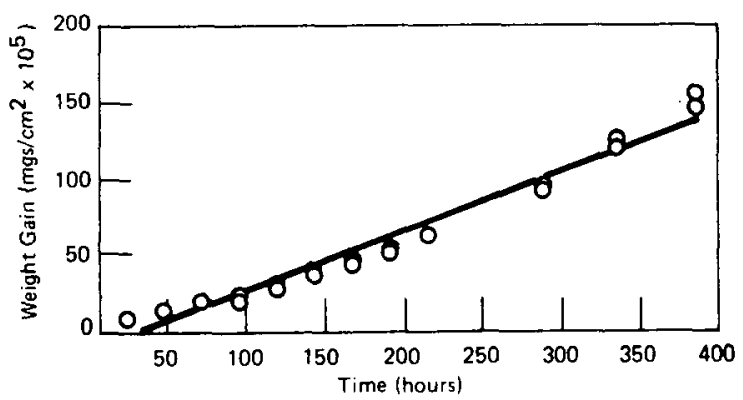

Figure 5. WEIGHT GAIN AS A FUNCTION OF TIME FOR THE FLUORINE-EXPOSED SAMPLES $(Y=A+B X$ FIT). fluorine. The extent of the lithium hydride and fluorine reaction and the thickness of the lithium fluoride layer are unknown. The weight-gain-versus-time relationship for the control and fluorine-treated samples can be seen by the graphs of Figures 4 and 5 , respectively, where linear fits were used. The parameters of the linear equation and statistics appear in Table 3. Thus, the fluorine treatment caused a 31 percent decrease in the rate of water pickup (slope of weight gain versus time relation), over a 385-hour exposure to dry-room air $110 \%$ $\mathrm{RH})$.

Table 3

PARAMETERS OF THE EQUATION $Y=A+B X$ AND SAMPLE STATISTICS FOR CONTROL AND FLUORINE GAS-EXPOSED SAMPLES

\begin{tabular}{lrr}
\hline & $\begin{array}{c}\text { Control } \\
\text { Samples }\end{array}$ & $\begin{array}{c}\text { Fluorine Gas- } \\
\text { Exposed } \\
\text { Samples }\end{array}$ \\
\hline Value of B & 0.556 & 0.386 \\
Standard Deviation of B & 0.010 & 0.013 \\
Value of A & 18.200 & 11.200 \\
Standard Deviation of A & 2.100 & 2.600 \\
95\% Confidence Limits of B & & \\
$\quad$ Upper & 0.578 & 0.412 \\
Lower & 0.535 & 0.359 \\
\hline
\end{tabular}


Both the fluorine-treated and control samples were examined by SEM, and were essentially identical microstructurally with each other and with the previously examined carbon dioxide-treated and control samples. The reacted layers of lithium fluoride and lithium carbonate were not seen in the SEM, probably because their layer thicknesses $(<100 \mathrm{~A})$ were less than the resolution of the instrument.

It appears from the data that a change of mechanism was not caused by either the carbon dioxide or fluorine treatments. The relationship between weight gain versus time remained linear for both treatments. 


\section{REFERENCES}

(1) Irvine, W. R. and Lund, J. A.; J Electrochem Soc, 110, p 141 (1963).

(2) Machin, W. D. and Tompkins, F. C.; Trans Faraday Soc, 62, p 2205 (1966).

(3) Pretzel, F. E., et al; J Phys Chem Solids, 16, p. 10 (1960). 


\section{ACKNOWLEDGEMENTS}

Appreciation is extended to R. K. Bennett and A. D. Condrey for the scanning electron micrographs presented in this report and to T. E. Zava for the use of the fluoriding service at the Oak Ridge Gaseous Diffusion Plant. 


\section{DISTRIBUTION}

Atomic Energy Commission - ORO

Keller, C. A.

Zachry, D. S., Jr

Lawrence Livermore Laboratory

Hickman, R. G.

Leider, H. R.

Los Alamos Scientific Laboratory

Alire, R. M.

Catlett, D. S.

Mound Laboratory

DeSando, R. J.

Oak Ridge Gaseous Diffusion Plant

Wilcox, W. J., Jr

Winkel, R. A.

Zava, T. E.

\section{Oak Ridge Y-12 Plant}

Bennett, R. B.

Briscoe, O. W.

Burditt, R. B.

Burkhart, L. E.

Denny, A. (2)

Fellers, H. L.

Hemphill, L. F.

Holcombe, C. E., Jr (5)

Keith, Alvin

Kite, H. T.
Mclntyre, J. M./Smith, H. M.

McLendon, J. D.

Mitchel, G. W.

Royer, L. T.

Schreyer, J. M.

Smith, J. H.

Smith, R. D.

Tench, F. M.

Tewes, W. E./Montgomery, C. D.

Weathersby, W. E.

Yaggi, W. J.

Y-12 Central Files (5)

$Y-12$ Central Files (master copy)

$Y-12$ Central Files (route)

$Y-12$ Central Files ( $Y-12 R C)$

Paducah Gaseous Diffusion Plant

Levin, R. W.

Sandia-Albuquerque

Prevender, T. S. (2)

Sandia-Livermore

Wayne, R. C. (2)

In addition, this report is distributed in accordance with the category UC-4, Chemistry, as given in the USAEC Standard Distribution Lists for Unclassified Scientific and Technical Reports, TID-4500. 